\title{
Analysis of a Decade in Library Literature: 1994-2004
}

\section{Kelly Blessinger and Michele Frasier}

\begin{abstract}
The purpose of this study was to analyze trends in publication and citation in library and information science journals over a decade (1994-2004) of the literature. This examination revealed the areas of concentration within the research, frequently published subjects through the years, and the characteristics of the top-cited authors and resources during this time. This information allows those in the field to follow the trends in publication, gives researchers the tools to determine which journals might give their work the most exposure and recognition, and can help libraries to make collection management decisions in this subject area.
\end{abstract}

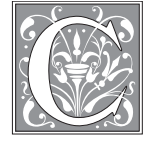

itation and content analysis within a field of literature can give insight into the development of a profession. An evaluation of the content of the literature can determine subject trends, thus revealing the major issues confronting the profession at a given period of time. Citation analysis data may be utilized for a number of purposes: as a tool to assist librarians making collection and weeding decisions; as a mechanism for discovering bibliometric trends; and as a way for publishers to track the competition. Moreover, citation and content studies have been adapted to a variety of research questions. Citation studies used to examine publication trends in specific academic disciplines can illustrate a number of interesting currents. Haiqi's examination of three prominent biology journals reveals that multiauthored articles are a growing trend in the field. In one journal studied, the average number of authors per article was 7.71. In addition, the author found that the "hot papers" (those articles receiving the greatest number of citations) in the field of biology had more funding sources as well as the participation of more institutions. ${ }^{1}$ In a bibliometric analysis of anthropology literature, Hider examined, among other things, the age of cited publications in anthropology journals as well as the form of cited material. He concluded that the age of cited references is dropping, for anthropologists no longer feel the obligation to cite the established literature. In addition, Hider contends that, in the United Kingdom, "books remain the most important literary form in anthropology." 2

Content analysis of library and information science (LIS) research is the central topic of several studies. A 1988 article by Atkins reviewed a decade of the literature from 1975 through 1985. His quantitative analysis of subject trends in LIS publishing illustrated "a heavy concentration on such automation-related subjects as information retrieval, databases, cataloging, library automation, technology, and research

Kelly Blessinger is Associate Reference Librarian in the Middleton Library at Louisiana State University; e-mail: kblessi@lsu.edu. Michele Frasier is Circulation, Instruction, and Reserves Librarian in the Linscheid Library at East Central University; e-mail: smccullr@mailclerk.ecok.edu. 
methods."3 Likewise, Buttlar's analysis of sixteen library journals reveals that automation was still a frequently discussed topic in library literature in the late 1980s. ${ }^{4}$ Other studies focused on subject coverage as well as the methodology behind the articles published. Examining over 800 articles from 1985, Järvelin and Vakkari divided the literature into two groups: research articles and professional articles (e.g., reviews, discussions, bibliographies). They found that, despite this division, the most frequent subjects in both groups were those discussing practical topics that involved the daily operations of libraries. ${ }^{5}$

Other articles have researched the authorship of the literature, or studied certain populations such as U.S. LIS faculty, ${ }^{6}$ LIS professionals in Africa, ${ }^{7}$ or U.K. LIS chair holders ${ }^{8}$ to determine publication productivity within these groups. Several studies found that academic librarians are major contributors to the body of literature. Yerkey's examination of 855 documents affirms that academic librarians published the greatest percentage of documents, followed by library school faculty and medical librarians. ${ }^{9}$ Another study on this topic found that academic librarians produced 43.6 percent $(1,579)$ of 3,624 articles examined. ${ }^{10}$ The articles previously mentioned also note that, since academic librarians far outnumber library school faculty, library school faculty are the most productive when analyzed on a percentage basis.

For this study, the authors chose to investigate several aspects within a recent decade (1994-2004) of LIS literature. First, the authors wished to examine what topics were being discussed within the scholarly communications to see what patterns emerged over the years. Second, the authors wanted to study citation patterns to determine the characteristics of the top-cited researchers and materials. Research into the highly cited authors would reveal the demographic of this group as a whole, and the analysis of the top-cited journals would illustrate whether authors were primarily using journals within the field for their research.

\section{Methodology}

Thomson's Journal Citation Reports (JCR) Social Science Edition was consulted to ascertain the journals of high repute within library and information science. This resource was chosen due to the high-quality standards for journals indexed in Thomson's journal citation products. ${ }^{11}$ Fifty-five journals appeared in the category of Library and Information Science in the JCR in 2003. Ulrich's Periodicals Directory was then consulted to ensure that the journals had the designation of Library and Information Sciences as a subject descriptor. This was done to eliminate the journals that focused mainly on information science. Ulrich's was also used to determine that the journals were indexed in both the Library Literature and the Social Sciences Citation In$\operatorname{dex}(S S C I)$ databases for the ten-year study period. The twenty-eight journals that met these criteria are listed in table 1, which is sorted by impact factor. Impact factor can be defined as "a measure of the frequency with which the 'average article' in a journal has been cited in a particular year or period. The annual JCR impact factor is a ratio between citations and recent citable items published." ${ }^{12}$ The impact factor of the 28 journals listed in the table averaged .542. From the list of twenty-eight journals, ten journals were randomly selected by the computer for inclusion in this study, and these journals are highlighted in table 1. A random sample of ten influential journals was thought to be representative of the trends of the literature as a whole during this time period, while also helping to keep the study at a manageable size. The ten journals studied reflect an average impact factor of .604, slightly above the mean.

Each journal studied was searched both in Library Literature and SSCI for the tenyear period of this study. Searches were limited strictly to journal articles in the databases to eliminate items such as book reviews, editorials, bibliographies, and letters to the editor. Each article's subjects and citations were edited for consistency and then imported into Microsoft Access for further analysis. If the information did 
not include all of the required fields such as author, cited year, and source, the citations were deleted. The group of deleted citations represented a small percentage of the total citations. While SSCI was used to do the citation analysis, the subject analysis was determined using the subjects listed in the indexing for Library Literature, as the subjects within the Library Literature database are much more detailed and consistent than those in SSCI.

\section{Results}

A total of 2,220 articles were published in

\begin{tabular}{|c|c|}
\hline \multicolumn{2}{|c|}{$\begin{array}{c}\text { TABLE } 1 \\
\text { Library and Information Science Journals that Met Criteria } \\
\text { (Those used in study are highlighted) }\end{array}$} \\
\hline Title & $\begin{array}{c}\text { Impact } \\
\text { Factor 2003 }\end{array}$ \\
\hline Journal of Documentation & 1.603 \\
\hline Journal of the American Society for Information Science and Technology & 1.473 \\
\hline College \& Research Libraries & 1.343 \\
\hline Information Processing \& Management & 1.179 \\
\hline Journal of Information Science & 1.067 \\
\hline Library Resources \& Technical Services & 0.923 \\
\hline Library and Information Science & 0.833 \\
\hline Library \& Information Science Research & 0.735 \\
\hline Journal of Academic Librarianship & 0.647 \\
\hline $\begin{array}{l}\text { Restaurator International Journal for the Preservation of Library and } \\
\text { Archival Material }\end{array}$ & 0.559 \\
\hline Library Quarterly & 0.485 \\
\hline ASLIB Proceedings & 0.459 \\
\hline Library Trends & 0.440 \\
\hline Online Information Review & 0.417 \\
\hline Journal of the Medical Library Association & 0.408 \\
\hline Law Library Journal & 0.326 \\
\hline Libri & 0.312 \\
\hline Reference \& User Services Quarterly & 0.312 \\
\hline Journal of Librarianship \& Information Science & 0.294 \\
\hline Interlending \& Document Supply & 0.273 \\
\hline Library Collections Acquisitions \& Technical Services & 0.231 \\
\hline Library Journal & 0.208 \\
\hline Information Technology and Libraries & 0.200 \\
\hline Knowledge Organization & 0.200 \\
\hline Journal of Government Information & 0.086 \\
\hline Canadian Journal of Information and Library Science & 0.071 \\
\hline Zeitschrift fur Bibliothekswesen und Bibliographie & 0.069 \\
\hline NFD Information-Wissenschaft und Praxis & 0.013 \\
\hline
\end{tabular}


the ten journals during the period of this study. The journals varied considerably in how many articles they published over this ten-year period. Library Trends published the most articles (434), while Library $\mathcal{E}$ Information Science published the least (56). Of the articles studied, 41 percent were written with the help of a second author, and 13 percent were written by three or more authors. This high collaboration rate has been noted in past studies on the literature within the profession as well. ${ }^{13,14}$ A 2000 article by Hart gives several reasons for this, such as increased quality with multiple authorship and higher acceptance in peer-reviewed journals. ${ }^{15}$

\section{Subjects}

The articles queried had an average of three subjects assigned to each article. Due to such a large number of subjects covered, the subjects were divided into 43 general subject categories. Once specific institutional names and personal names were excluded, the subjects were grouped into five major categories. The categories (ranked by percentage of subjects that fell within that topic) were:

1. Library Operations (33\%)

2. Research in Library and Information Science/Users (20\%)

3. Library/Information 1Science Profession (18\%)

4. Technology (18\%)

5. Publishing/Publishing Studies (11\%)

See Appendix A for the list of which subjects fell under various categories. The reader can tell from the results that practical items are still what is highly discussed within the literature. As our profession changes with new technologies, the literature naturally reflects this. Most of the subjects within the categories experienced periods of low and high discussion within the literature.

The subjects most covered within Library Operations included cataloging, reference/information services, and user instruction and education. Cataloging peaked in 1997 with articles regarding automation. Traditional subjects including classification systems and authority control were also discussed frequently during the study period. Other popular subjects within cataloging that reflected the increase of technology that dominated this decade include metadata and the cataloging of Internet Web sites. The subject of reference/information services rose from 1999 to its peak in 2001, with articles primarily on automation and virtual libraries. Since many libraries were looking into or had implemented virtual chat services during this time, this could easily explain the popularity of this subject. The evaluation of reference/information services was a traditional topic that was popular during this time period as well. User instruction/education rose sharply in prevalence in the literature from 2000 to 2001, with a large number of articles on bibliographic instruction geared toward college and university students. The big push toward information literacy during this time is most likely accountable for this trend. Other topics that were popular within this subject include computer-assisted instruction and distance education. Due to the plethora of resources that became available electronically during the time of this study, computer-assisted instruction became the norm as more students were able to access materials electronically and to take classes and obtain degrees from a distance.

In the category of Research in Library and Information Science/Users, the popular topics were user studies, information retrieval, and theoretical issues. User studies were popular as a research method for many of the articles. The studies were primarily conducted by surveys and use statistics. This is consistent with findings of an earlier study, which stated that the methods of research in library and information science are "heavily concentrated in the survey, historical, and observation and description methods." 16 Some of the more popular topics for studies included information needs, the Internet, online catalogs, and serial publications. Articles 
on information retrieval reached a peak in 1999. All of the new electronic indexes and databases no doubt revived interest in how users retrieved information through this new media. While there were many articles regarding the evaluation of information retrieval, there was also a large portion that focused on the social aspects of the topic. Of the theoretical topics covered, the most popular were cognition, information theory, philosophical aspects of information science, knowledge management, and ethics. Academic and research libraries were the types of institutions most discussed across all subjects, particularly within the category of Library/Information Science Profession, followed by public libraries. Some popular topics discussed within librarianship and professional issues included relations with faculty and curriculum, the status of librarians in general-particularly academic librarians - philosophical aspects of the profession, as well as various careers within the field. The subjects that fell into the Technology category mainly covered the Internet, information science, indexes and databases, and automation. The Internet, as we all know, has changed most aspects of our profession, so it is no surprise that it was heavily discussed during this decade. In 1994 there were very few articles on this subject, but research increased with a peak in 2001. The most popular topics within this subject were the design and evaluation of Web sites, likely due to libraries making their Web presence known during this decade. Other topics included Web portals and the Internet in general. Information science peaked as a subject in 1997, when the design of information systems was a frequently published subject. Other frequently published subjects within information science included optical data processing and open source software. Popular topics within indexes/databases included databases in the humanities, databases with pictures and full-text databases. Automation was the one subject within technology that demonstrated a sharp decline during the period of this study. The subject was a popular topic until it peaked in 1997 and has been decreasing in popularity since then. In the category of Publishing/Publishing Studies, articles on serials and bibliometrics were the most common. In serials, the most popular topic was the evaluation of serials, specifically scientific and library and information science jour-

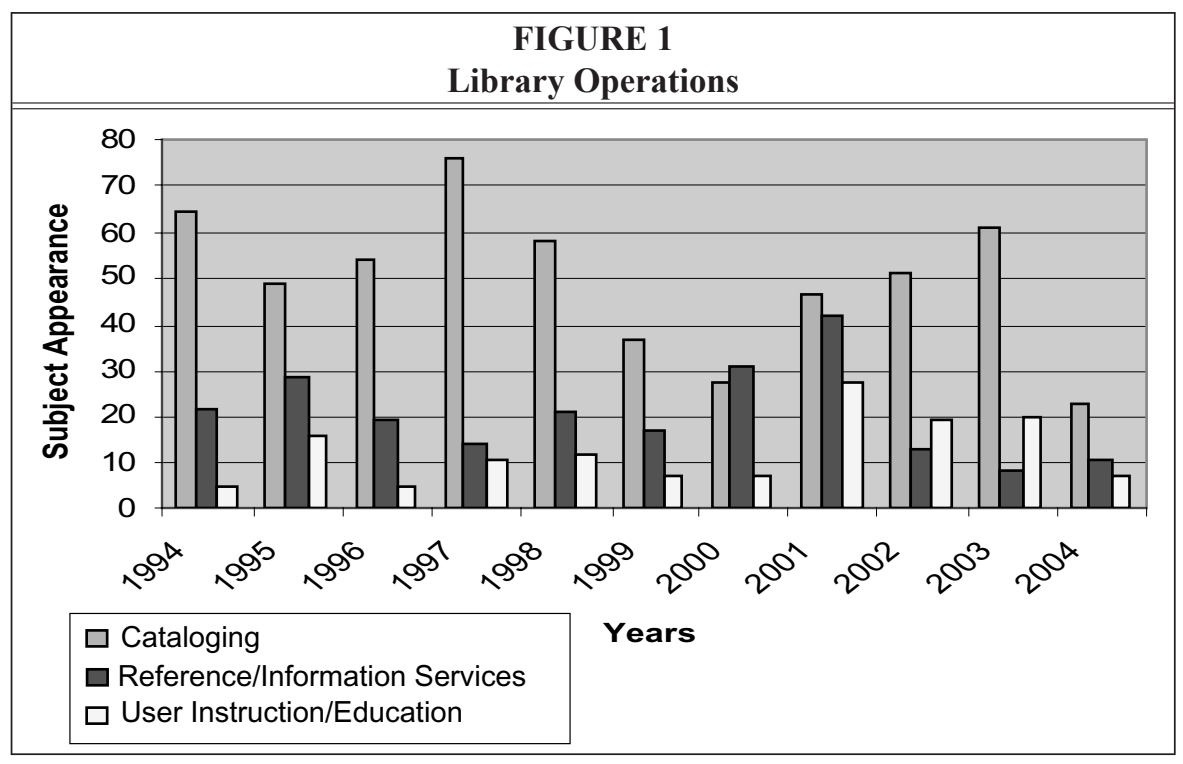




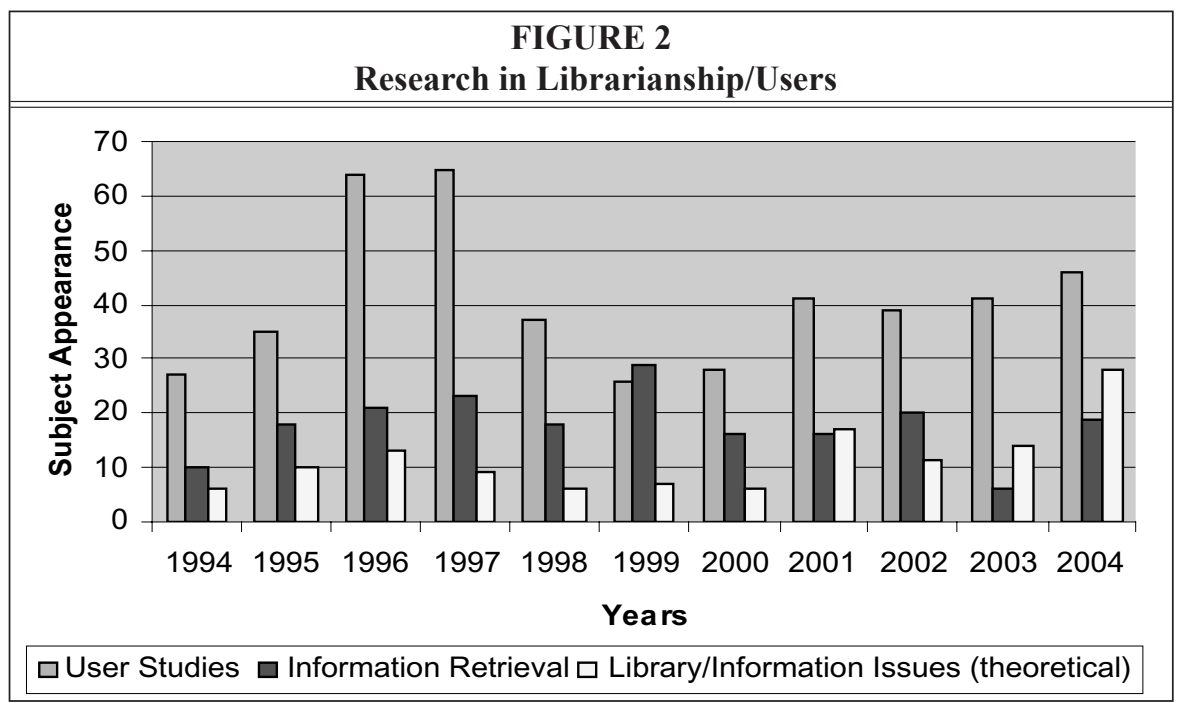

nals. Escalating serial costs, particularly in the sciences, forced libraries to evaluate their collections during this decade. For a graphical display of the top subjects in the categories, refer to figures $1-5$. The top twenty-five overall subjects written about from 1994-2004 are listed in table 2.

\section{Citations}

Of the 47,389 citations listed by the journals studied, 19,482 (41\%) were from sources cited only once. Materials cited in articles during the period studied ranged in pub- lication date from 1605 through 2004. The majority of articles cited fell in the more recent date range, with 62 percent of the articles cited published from 1990 to 2004. Journals with over 100 citations attributed to them are listed in table 3. Most of the journals fell squarely into the subject area of Library and Information Science, but the few that did not (in order of times cited) were Communications of the ACM (Association for Computing Machinery) which is primarily an information science publication, and Science, a well-known and highly

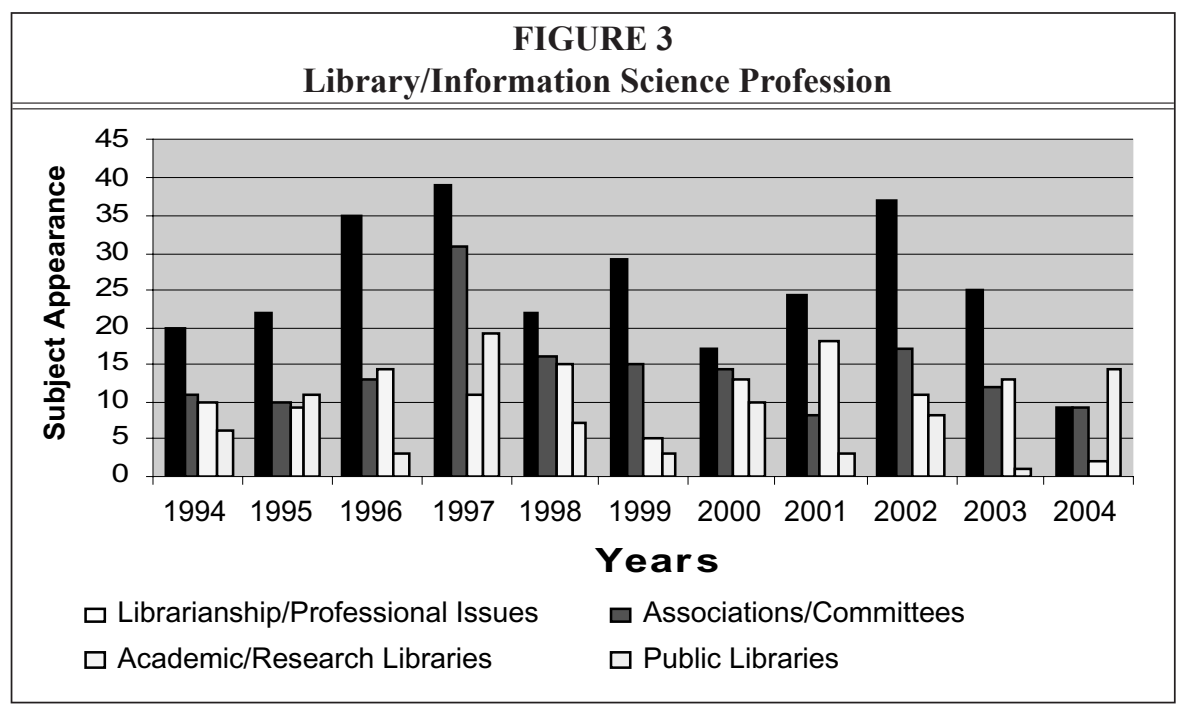




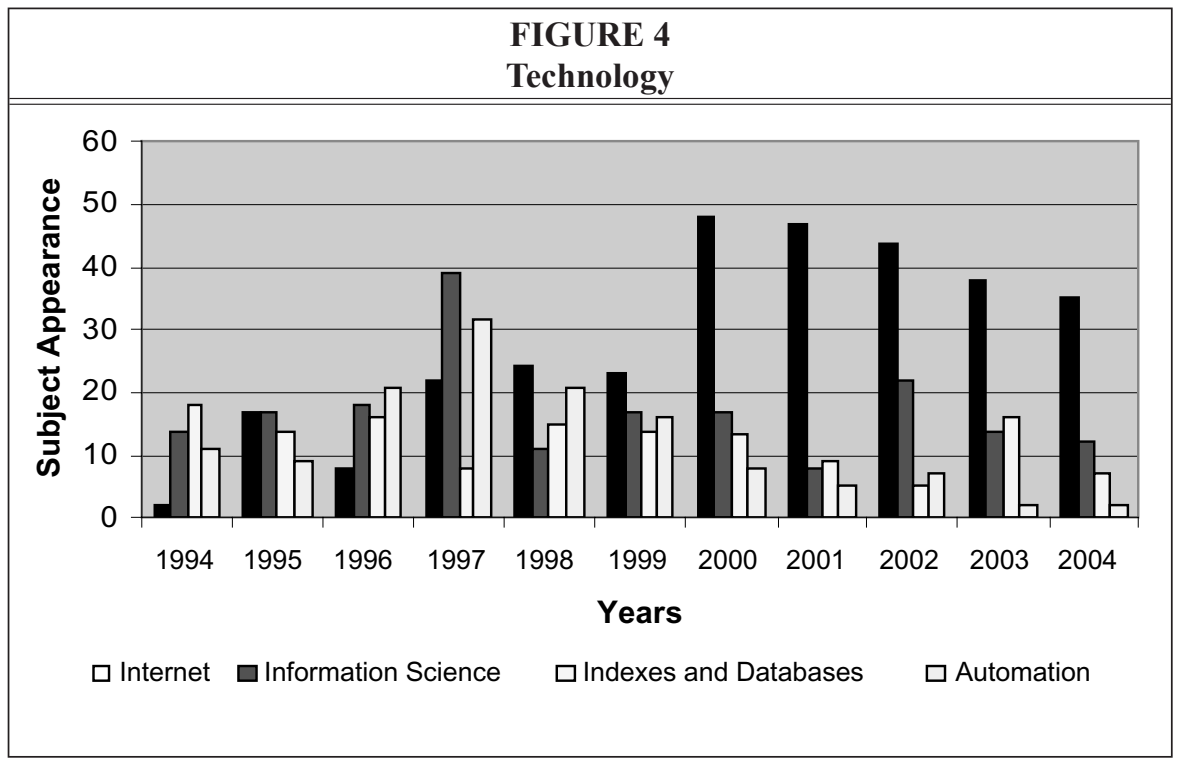

regarded general science journal. This table provides information on all of the journals that were heavily cited by the ten journals studied, not just those indexed by $S S C I$, as the JCR product provides. The result is a more complete list of what journals were heavily cited during this decade.

\section{Authors}

There were a total of 21,994 unique authors cited in this study, with 69 percent of these authors cited only once. The top-cited au- thors are listed in Table 4. The list contains the authors who had more than fifty citations attributed to their work in the journals queried in this study. The authors are listed in descending order of total citations to materials written by them. The reader should note that the number listed under the "times cited in study" column is the number of citations that were culled from the specific journals studied for this article, not all journals over this time period. When there was a tie between the authors who

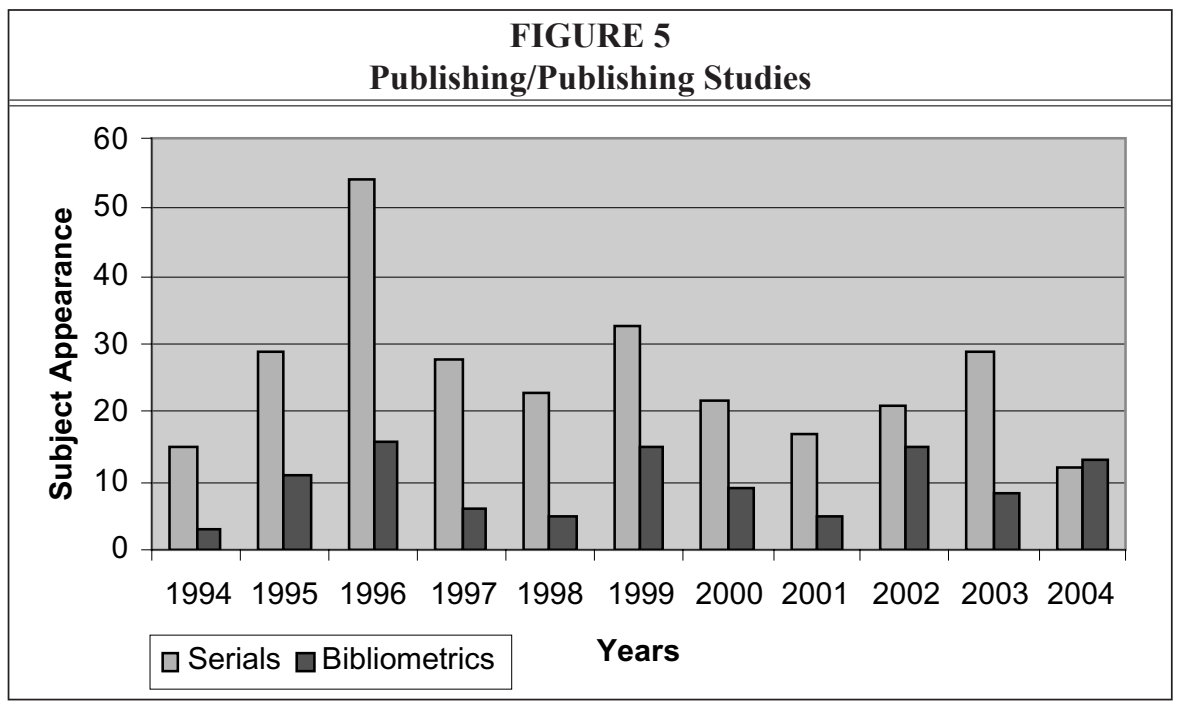


had the same number of citations to their work in this study, this was indicated by a (T). The "works cited" column indicates how many different works were cited for each author during the period of this study. As the reader can tell, the highly cited authors are also very prolific. The average number of different works cited by authors on this list was forty. Although Birger Hjorland received the most citations to his work in this study (165), Stephen Wiberley, who tied for 28 th place with 50 citations to his work, had the highest average number of citations per work (4.2). The SSCI record contains the author's address as one of its fields, so this source was consulted to find the affiliation of the authors for their most cited work. The institutions' Web pages were then checked to see if they were currently affiliated with that institution in 2005. The top researchers are overwhelmingly af-

\begin{tabular}{|c|c|c|}
\hline \multicolumn{3}{|c|}{$\begin{array}{c}\text { TABLE } 2 \\
\text { Top Subjects from } 1994 \text { through } 2004\end{array}$} \\
\hline Rank & Subject & $\begin{array}{c}\text { Times } \\
\text { Covered }\end{array}$ \\
\hline 1 & Cataloging & 548 \\
\hline 2 & User Studies & 449 \\
\hline 3 & Internet & 308 \\
\hline 4 & Serials & 283 \\
\hline 5 & Librarianship/Professional Issues & 279 \\
\hline 6 & Reference/Information Services & 227 \\
\hline 7 & Information Retrieval & 196 \\
\hline 8 & Information Science & 189 \\
\hline 9 & Associations/Committees & 156 \\
\hline 10 & User Instruction/Education & 136 \\
\hline 11 & Indexes/Databases & 135 \\
\hline 12 & Automation & 134 \\
\hline 13 & Library/Information Issues (theoretical) & 127 \\
\hline 14 & Academic/Research Libraries & 121 \\
\hline 15 & Bibliometrics & 106 \\
\hline 16 & Library/Information Issues (practical) & 104 \\
\hline 17 & Administration & 97 \\
\hline 18 & Collection Development & 93 \\
\hline 19 & Information Needs & 88 \\
\hline 20 & Public Libraries & 85 \\
\hline 21 & Publishing/Publishers & 82 \\
\hline 22 & Library/Information networks & 77 \\
\hline 23 & Research Methodology & 72 \\
\hline 24 & Literature Evaluation & 71 \\
\hline 25 & Indexing/Abstracting & 62 \\
\hline
\end{tabular}
filiated with academic in-

stitutions, specifically with LIS programs. It was found that most of the top-cited authors were full professors or of high academic rank at their institutions, indicating that they had worked in that capacity for some time. Only a few authors fell out of this category. Several institutions had more than one highly cited researcher, including the Royal School of Library and Information Science in Denmark, Rutgers University, UCLA, and Indiana University. All of these programs except the Royal School of Library and Information Science are ALA accredited and offer Ph.D. programs in Library and Information Science. A majority $(75 \%)$ of the authors are currently working in the United States, with only eight highly cited LIS researchers currently working in other locales. The other areas represented include Denmark, the United Kingdom, and India. This is consistent with findings from other studies, such as a 1993 article on international librarianship that "revealed a dominance by the more industrialized countries, which published the majority of documents." ${ }^{17}$ 


\begin{tabular}{|c|c|c|}
\hline \multicolumn{3}{|c|}{\begin{tabular}{|c|} 
TABLE 3 \\
$\begin{array}{c}\text { Top Quartile of Journals Cited, 1994-2004 } \\
\text { (Those listed in Table 1 are highlighted) }\end{array}$ \\
\end{tabular}} \\
\hline Rank & Source & $\begin{array}{l}\text { Times } \\
\text { Cited }\end{array}$ \\
\hline 1 & Journal of the American Society for Information Science & 1516 \\
\hline 2 & College \& Research Libraries & 1440 \\
\hline 3 & Journal of Documentation & 828 \\
\hline 4 & Journal of Academic Librarianship & 654 \\
\hline 5 & Library Journal & 558 \\
\hline 6 & Library \& Information Science Research & 498 \\
\hline 7 & Library Trends & 454 \\
\hline 8 & Library Quarterly & 419 \\
\hline 9 & Reference \& User Services Quarterly & 407 \\
\hline 10 & Information Processing \& Management & 369 \\
\hline 11 & Library Resources \& Technical Services & 298 \\
\hline 12 & Journal of Information Science & 296 \\
\hline 13 & Scientometrics & 244 \\
\hline 14 & American Libraries & 218 \\
\hline 15 & Information Technology \& Libraries & 216 \\
\hline 16 & Cataloging \& Classification Quarterly & 210 \\
\hline 17 & Bulletin of the Medical Library Association & 201 \\
\hline 18 & Journal of Library Administration & 190 \\
\hline 19 & Annual Review of Information Science \& Technology & 176 \\
\hline 20 & Collection Management & 173 \\
\hline 21 & Reference Librarian & 167 \\
\hline 22 & Communications of the ACM & 163 \\
\hline 23 & Research Strategies & 158 \\
\hline 24 & Serials Librarian & 134 \\
\hline 25 & ONLINE & 133 \\
\hline 26 & Reference Services Review & 131 \\
\hline 27 & ASLIB Proceedings & 131 \\
\hline 28 & Library Administration \& Management & 124 \\
\hline 29 & Library Acquisitions-Practice and Theory & 122 \\
\hline 30 & Computers in Libraries & 117 \\
\hline 31 & College \& Research Libraries News & 114 \\
\hline 32 & Knowledge Organization & 114 \\
\hline 33 & Information Technology & 108 \\
\hline 34 & Science & 106 \\
\hline 35 & Serials Review & 102 \\
\hline 36 & Journal of Librarianship and Information Science & 100 \\
\hline
\end{tabular}




\begin{tabular}{|c|c|c|c|c|}
\hline & Most Cited Pe & $\begin{array}{c}\text { TABLE } 4 \\
\text { rsonal Authors, 1994-2004 (in rank }\end{array}$ & rder) & \\
\hline Rank & Author & "Most Recent Affiliation/Department & $\begin{array}{l}\text { Times } \\
\text { Cited in } \\
\text { Study }\end{array}$ & $\begin{array}{l}\text { Works } \\
\text { Cited }\end{array}$ \\
\hline 1 & Birger Hjorland & $\begin{array}{l}\text { Royal School of Library and } \\
\text { Information Science, Denmark/ } \\
\text { Department of Information Studies }\end{array}$ & 165 & 56 \\
\hline 2 & Brenda Dervin & $\begin{array}{l}\text { Ohio State University/School of } \\
\text { Communication }\end{array}$ & 135 & 52 \\
\hline 3 & Carol Kuhlthau & $\begin{array}{l}\text { Rutgers University/School of } \\
\text { Communication, Information and } \\
\text { Library Studies }\end{array}$ & 131 & 38 \\
\hline 4 & Blaise Cronin & $\begin{array}{l}\text { Indiana University/School of Library } \\
\text { and Information Science }\end{array}$ & 127 & 65 \\
\hline 5 & Peter Hernon & $\begin{array}{l}\text { Simmons College/Graduate School of } \\
\text { Library and Information Science }\end{array}$ & 117 & 62 \\
\hline 6 & Marcia Bates & $\begin{array}{l}\text { UCLA/ Graduate School of Education } \\
\text { and Information Studies }\end{array}$ & 105 & 40 \\
\hline 7 & Peter Ingwersen & $\begin{array}{l}\text { Royal School of Library and } \\
\text { Information Science, Denmark/ } \\
\text { Department of Information Studies }\end{array}$ & 101 & 43 \\
\hline $8(\mathrm{~T})$ & F.W. Lancaster & $\begin{array}{l}\text { University of Illinois at Urbana- } \\
\text { Champaign/ Graduate School of } \\
\text { Library and Information Science }\end{array}$ & 100 & 58 \\
\hline $8(\mathrm{~T})$ & Gerard Salton & $\begin{array}{l}\text { Cornell/Computer Science (deceased } \\
\text { 1995) }\end{array}$ & 100 & 52 \\
\hline 9 & Tefko Saracevic & $\begin{array}{l}\text { Rutgers University/School of } \\
\text { Communication, Information and } \\
\text { Library Studies }\end{array}$ & 99 & 44 \\
\hline $10(\mathrm{~T})$ & Eugene Garfield & $\begin{array}{l}\text { President and Editor-in-Chief of The } \\
\text { Scientist/Founder and Chairman } \\
\text { Emeritus of the Institute of Scientific } \\
\text { Information }\end{array}$ & 98 & 70 \\
\hline $10(\mathrm{~T})$ & Tom Wilson & $\begin{array}{l}\text { University of Sheffield/The Department } \\
\text { of Information Studies }\end{array}$ & 98 & 27 \\
\hline 11 & David Ellis & $\begin{array}{l}\text { University of Wales/Information } \\
\text { Studies }\end{array}$ & 96 & 31 \\
\hline $12(\mathrm{~T})$ & Nicholas Belkin & $\begin{array}{l}\text { Rutgers University/School of } \\
\text { Communication, Information and } \\
\text { Library Studies }\end{array}$ & 92 & 39 \\
\hline $12(\mathrm{~T})$ & Christine Borgman & $\begin{array}{l}\text { UCLA/ Graduate School of Education } \\
\text { and Information Studies }\end{array}$ & 92 & 42 \\
\hline 13 & Charles McClure & $\begin{array}{l}\text { Indiana University/School of Library } \\
\text { and Information Science }\end{array}$ & 91 & 52 \\
\hline 14 & Amanda Spink & $\begin{array}{l}\text { University of Pittsburgh/School of } \\
\text { Information Sciences }\end{array}$ & 81 & 44 \\
\hline
\end{tabular}




\begin{tabular}{|c|c|c|c|c|}
\hline \multicolumn{5}{|c|}{$\begin{array}{c}\text { TABLE } 4 \\
\text { Most Cited Personal Authors, 1994-2004 (in rank order) }\end{array}$} \\
\hline Rank & Author & Most Recent Affiliation/Department & $\begin{array}{l}\text { Times } \\
\text { Cited in } \\
\text { Study }\end{array}$ & $\begin{array}{l}\text { Works } \\
\text { Cited }\end{array}$ \\
\hline 15 & Raya Fidel & $\begin{array}{l}\text { University of Washington/Information } \\
\text { School }\end{array}$ & 79 & 25 \\
\hline 16 & Maurice Line & $\begin{array}{l}\text { British Library, library consultant, } \\
\text { editor Alexandria The Journal of } \\
\text { National and International Library and } \\
\text { Information Issues (retired) }\end{array}$ & 76 & 40 \\
\hline 17 & Carol Tenopir & $\begin{array}{l}\text { University of Tennessee/School of } \\
\text { Information Sciences }\end{array}$ & 73 & 53 \\
\hline 18 & S.R. Ranganathan & $\begin{array}{l}\text { Documentation Research and Training } \\
\text { Center, Bangalore, India, founder, } \\
\text { professor, and director (deceased 1972) }\end{array}$ & 72 & 54 \\
\hline 19 & Patrick Wilson & $\begin{array}{l}\text { University of California, Berkeley/ } \\
\text { School of Library and Information } \\
\text { Studies (deceased 2003) }\end{array}$ & 71 & 32 \\
\hline 20 & Gary Marchionini & $\begin{array}{l}\text { University of North Carolina/School of } \\
\text { Information and Library Science }\end{array}$ & 70 & 34 \\
\hline 21 & Elfreda Chatman & $\begin{array}{l}\text { Florida State University/School of } \\
\text { Information Studies (deceased 2002) }\end{array}$ & 66 & 16 \\
\hline 22 & Michael Gorman & $\begin{array}{l}\text { California State University, Fresno/ } \\
\text { Dean of Library Services at the Henry } \\
\text { Madden Library }\end{array}$ & 61 & 42 \\
\hline 23 & Stephen Harter & $\begin{array}{l}\text { Indiana University/School of Library \& } \\
\text { Information Science (retired) }\end{array}$ & 60 & 28 \\
\hline 24 & Michael Buckland & $\begin{array}{l}\text { University of California, Berkeley/ Co- } \\
\text { Director of the Electronic Cultural Atlas } \\
\text { Initiative and Emeritus Professor in the } \\
\text { School of Information Management and } \\
\text { Systems }\end{array}$ & 59 & 31 \\
\hline 25 & Mike Thelwall & $\begin{array}{l}\text { University of Wolverhampton/ School } \\
\text { of Computing and Information } \\
\text { Technology }\end{array}$ & 56 & 30 \\
\hline 26 & John Budd & $\begin{array}{l}\text { University of Missouri/School of } \\
\text { Information Science \& Learning } \\
\text { Technologies }\end{array}$ & 55 & 35 \\
\hline 27 & Walt Crawford & Senior Analyst, RLG & 53 & 29 \\
\hline $28(\mathrm{~T})$ & Bertram Brookes & $\begin{array}{l}\text { University College, London/School } \\
\text { of Library, Archive, and Information } \\
\text { Studies, visiting professor other } \\
\text { universities (deceased 1991) }\end{array}$ & 50 & 33 \\
\hline $28(\mathrm{~T})$ & $\begin{array}{l}\text { Stephen Wiberley } \\
\text { Jr. }\end{array}$ & $\begin{array}{l}\text { University of Illinois Chicago/ } \\
\text { University Library }\end{array}$ & 50 & 12 \\
\hline
\end{tabular}


Most of the authors listed are still actively working within the profession, with the exception of two who have retired and five who are deceased. Although LIS is still a female-dominated profession, most of the top-cited researchers were male, with a 75 percent representation of the whole. While studies indicate that men were much more prevalent in the literature in the past, the same studies now show that the gap is closing in regard to gender and publication. A 1999 study on the history of the journal JASIS shows that participation in female authorship increased over the years from 33 percent in 1955 to 43 percent in $1995 .{ }^{18}$ Likewise, a 1996 article that studied College $\mathcal{E}$ Research Libraries articles found that, for the first time since its publication, the number of articles primarily authored by women equaled that of men from 1989 through 1994, and the total number of women authors was more than that of men. ${ }^{19} \mathrm{~A}$ shift in citations may soon reflect this trend as well.

\section{Conclusion}

The analysis of LIS literature over a decade illustrated that librarians are still largely writing about the practical issues that face the profession. As the issues change, our literature reflects these currents. Naturally, new technologies in information science, most notably the Internet, had a tremendous impact on almost every aspect of our profession during this decade. An analysis of authorship shows the highly collaborative nature of the profession, and citation research indicates that primarily journals within the field are used for research. Knowing which journals are highly cited is helpful to authors submitting scholarly work by helping them to determine where their research might have the largest use and influence. Additionally, the list will help them to determine which journals may be held in the highest regard for performance appraisals, promotion, and tenure decisions. When used in conjunction with other information such as local use data, this could also assist libraries in making collection management and help publishers track their competition within the field. The list of highly cited authors revealed whose research within the field was well known and respected during this decade, although the demographics are different from the profession as a whole. While prior studies indicate that academic librarians and LIS educators publish at nearly the same rate, it is clear from the data gathered during this study that LIS educators dominate the list of authors who are highly cited. Reasons for this differential citation rate would be an interesting basis for further study. The snapshot in time of the top-cited researchers will allow those who wish to do studies in the future on the field's highly cited authors to compare trends over time in demographics such as gender, institutional affiliation, and job position. It could also serve to help those considering a Ph.D. in the field to determine which universities have professors who are highly cited within the literature. Periodic evaluation of the literature is important because it grants insight into the evolution of the profession by revealing the issues, resources, and researchers that are of importance to our field.

\section{Notes}

1. Zhang Haiqi, "More Authors, More Institutions and More Funding Sources: Hot Papers in Biology from 1991 to 1993," Journal of the American Society for Information Science 48 (July 1997): 662-66.

2. Philip M. Hider, "Three Bibliometric Analyses of Anthropology Literature," Behavioral \& Social Sciences Librarian 15, no. 1 (1996): 1-17.

3. Stephen E. Atkins, "Subject Trends in Library and Information Science Research, 19751984." Library Trends 36 (Spring 1988): 633-58.

4. Lois Buttlar, "Analyzing the Library Periodical Literature: Content and Authorship," College \& Research Libraries 52 (Jan. 1991): 39-53. 
5. Kalervo Järvelin and Pertti Vakkari, "Content Analysis of Research Articles in Library and Information Science," Library \& Information Science Research 12 (Oct.-Dec. 1990): 395-421.

6. John Budd, "Scholarly Productivity of U.S. LIS Faculty: An Update," Library Quarterly 70, no. 2 (2000): 230-45.

7. L. O. Aina and Patricia Neo Mooko, "Research and Publication Patterns in Library and Information Science," Information Development 15, no. 2 (1992): 114-19.

8. Blaise Cronin and Elisabeth Davenport, "Profiling the Professors," Journal of Information Science 15, no. 1 (1989): 13-20.

9. A. Neil Yerkey, "Publishing in Library and Information Science: Audience, Subjects, Affiliation, Source, and Format," Library \& Information Science Research 15 (Spring 1993): 165-84.

10. Ann C. Weller, Julie M. Hurd, and Stephen Wiberley, "Publication Patterns of U.S. Academic Librarians from 1993 to 1997," College \& Research Libraries 60, no. 4 (1999): 352-62.

11. Thomson Scientific, "The Thomson Scientific Journal Selection Process." Available online from http://scientific.thomson.com/free/essays/selectionofmaterial/journalselection. [Accessed 5 December 2005].

12. Thomson Scientific, “The ISI Impact Factor." Available online from http://scientific.thomson. com/free/essays/journalcitationreports/impactfactor. [Accessed 18 January 2006].

13. James L. Terry, "Authorship in College \& Research Libraries Revisited: Gender, Institutional Affiliation, Collaboration," College \& Research Libraries 57 (July 1996): 377-83.

14. Ben-Ami Lipetz, "Aspects of JASIS Authorship through Five Decades," Journal of the American Society for Information Science 50, no. 11 (1999): 994-1003.

15. Richard L. Hart, "Co-authorship in the Academic Library Literature: A Survey of Attitudes and Behaviors," Journal of Academic Librarianship 26, no. 5 (2000): 339-45.

16. Patricia E. Feehan, W. Lee Gragg II, W. Michael Havener, and Diane D. Kester, "Library and Information Science Research: An Analysis of the 1984 Journal Literature," Library \& Information Science Research 9 (July 1987): 173-85.

17. Nonie Janet Bliss, "International Librarianship: A Bibliometric Analysis of the Field," International Information \& Library Review 25 (June 1993): 93-107.

18. Lipetz, "Aspects of JASIS Authorship," 994-1003.

19. Terry, "Authorship in College \& Research Libraries Revisited," 377-83.

\section{Elegant Solutions for Preservation}

Call for a complete catalog

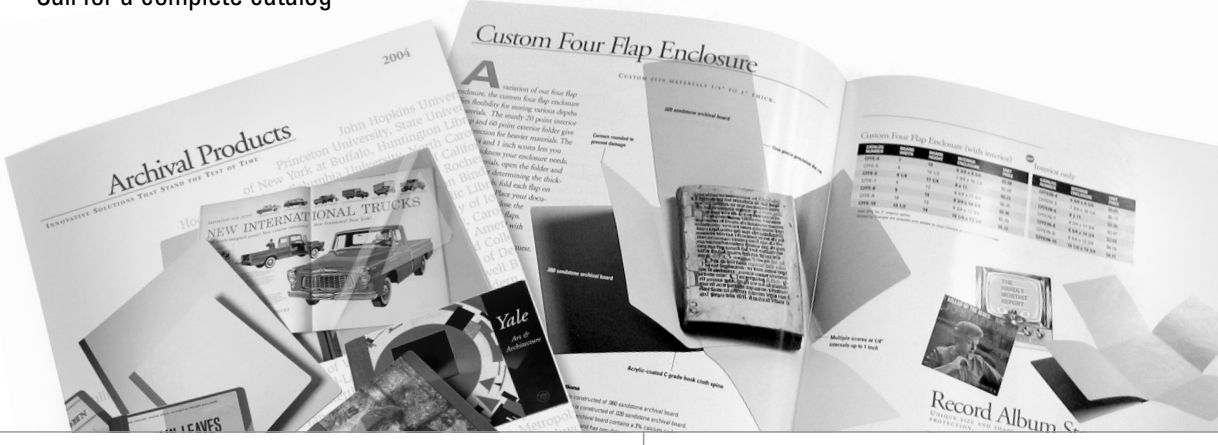

Pamphlet Binders Music Binders Archival Folders Manuscript Folders Hinge Board Covers Academy Folders Newspaper/Map Folders Polypropylene Sheet \& Photo Protectors

Conservation \& Preservation Tapes
Bound Four Flap Enclosures Archival Binders Archival Boards Adhesives Bookkeeper Century Boxes Record Album Enclosures Conservation Cloths

\section{ARCHIVAL PRODUCTS}

P.O. Box $1413 \mid$ Des Moines, Iowa 50305-1413 800.526.5640 | Fax 888.220.2397 custserv@archival.com I www.archival.com 


\section{APPENDIX A}

\section{Category}

Library Operations

\section{Subject}

Number

1,624

Cataloging 548

Reference/Information Services

User Instruction/Education

136

Library/Information Issues (practical) 104

Administration 97

Collection Development 93

Indexing/Abstracting

Acquisitions 62

Interlibrary Loan 60

Public Relations 56

Communications

Library Finance

Circulation

Library Staff

Disability Services

Library Environment

Research in Librarianship/

Users

User Studies

Information Retrieval

Library/Information Issues (theoretical)

Information Needs

Research Methodology

Research in Librarianship

Library/Information Science Research

Library/Information

Science Profession

Librarianship/Professional Issues

Associations/Committees

Academic/Research Libraries

Public Libraries

Library/Information networks

LIS Education

Special Collections/Libraries

Archives/Preservation

Children's Libraries/Materials 
Technology

Internet

Information Science

Indexes/Databases

Automation

Software

Electronic Publishing

Publishing/Publishing

Bibliometrics

Publishing/Publishers

Literature Evaluation

Monographic Publications

\section{SIL International ВоОтн}

ACRL March 29-3I, 2007 in Baltimore

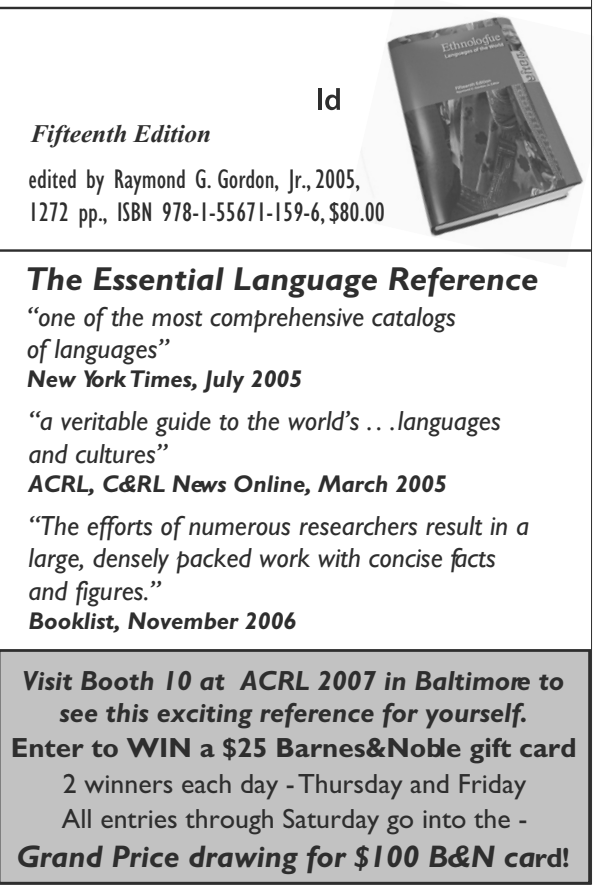

